\title{
BRICS Dream: BRICS in International Stabilization and Reconstruction Efforts
}

\author{
Arodh Lal Karn*, Rakshha Kumari Karn \\ School of Management, Harbin Institute of Technology, Harbin, China \\ Email: "alkmaithili@gmail.com
}

Received 8 May 2016; accepted 13 June 2016; published 16 June 2016

Copyright (C) 2016 by authors and OALib.

This work is licensed under the Creative Commons Attribution International License (CC BY).

http://creativecommons.org/licenses/by/4.0/

(c) (i) Open Access

\begin{abstract}
Almost most of the states are concerned about the potential spillover of insecurity from U.S. ambitious dream to remain super power and control over worlds resources, potentially leading to regional destabilization, with negative consequences for the region, including the potential impact of militant activities, the spread of radical Islamist ideas, increased drug trafficking and refugee crises. Despite these common fears, policies of BRICS-states toward region and world, focuses on the future of international stabilization efforts and further prospects for increasing ties and trade holds. For this the paper has first necessary explored the broader geopolitical context. BRICS states do have sufficient capacity to significantly influence prosperity, restore the lost trust on allies and cooperation in the region. No matter, world states are constrained by complex geopolitics of place and intra-regional rivalries, "BRICS BREAM" should grow stronger for international stabilization and reconstruction efforts.
\end{abstract}

\section{Keywords}

BRICS Dream, Geopolitics; Arm Race, International, Stabilization

Subject Areas: International Relations, Politics

\section{Introduction}

This paper uses a comparative approach to argue that there are many commonalities and differences in the policies of the BRICS and other world allies, and a variety of views in the region on the security situation, the future of international stabilization efforts, the implications of the withdrawal of the International Security Assistance Force (ISAF) and further prospects for increasing ties and trade. The approaches and policies of BRICS can be explained by referring to factors such as its proximity to and existing links, vulnerability and

${ }^{*}$ Corresponding author. 
capacity as allies, its perspectives and attitudes, and its foreign-policy style, along with complex intraregional politics and the geopolitical context.

Discussions and estimates of the security and wealth-creation potential of developing more ties and trade between Central Asia and South Asia by BRICS nations as a bridge continue, although the level of skepticism about the feasibility of these plans has been growing [1].

The BRICS must achieve anything that could be described as "Regional order". Few people would dispute the existence of a relationship between economic, social and human development, on the one hand, and peace and security, on the other. The relationship is complex: while security can lead to development and development can lead to security, neither is sufficient to promote the other and both may not always be necessary, in the short term [2]. The continuous movement from seeking common ground to tolerating national differences and managing their consequences has progressively corroded multilateral approaches and, as the security discourse escapes the confinement of agreed frameworks, a new fluidity can be seen in the alignment of states over different issues [3]. Better understanding of this relationship will require more research, using an approach that concentrates on analyzing problems in their entirety, rather than focusing on trying to solve the individual elements. In order to understand how the different parts of these problems interact, it will be necessary to draw from many academic disciplines. Understanding the interaction between science and public policy has also become more of a challenge.

The analysis of commonalities and differences and underlying causes allows tentative answers to the following questions: Does BRICS can assist in shaping regional and international security concern challenges and how BRICS can best contribute to stabilization efforts in regions? Are the trends towards connectivity between Central Asia and its neighborhoods in South Asia, which began with the collapse of the Soviet Union, growing stronger due to BRICS formation?

Chapter 2 provides a brief overview of geopolitics and weapons transfer. Chapter 3 discusses Perspectives of BRICS in international stabilization and reconstruction efforts. Chapter 4 presents conclusions.

\section{Return of Geopolitics}

There are four big unfolding geopolitical stories: BRICS rise, G8 to G20 to G-Zero, Middle East turmoil and the redesign of Europe. The G-Zero is not the new world order. It's a period of transition. Decision makers of five countries build new systems, alliances, and global institutions and named as BRICS. Leaders of BRICS will act to try to ensure that transnational challenges don't threaten their countries' security, wealth, and privileges. There are many countries now strong enough to block international action, but none is both willing and able to bring about lasting positive change. The result is a lack of global leadership. Diversification has always been an essential tool for managing risk [4]. The political relationship between Russia and a spectrum of Western countries deteriorated rapidly, and some institutional relationships such as those between the North Atlantic Treaty Organization (NATO) and Russia, and Russia and the European Union (EU) have been damaged irrevocably. The decisions taken by NATO leaders at the Wales Summit towards the end of 2014 could include the regeneration of larger military forces configured for territorial defence to restore deterrence as a central element in the security policy of European NATO allies [5]. Russia's attempts to raise its profile in North East Asia are likely to have a major strategic impact in BRICS. China and India have become increasingly active in regional counterterrorism cooperation as a result of a rise in domestic jihadist attacks, concerns about a spillover of instability from Afghanistan associated with the drawdown and closure of the International Security Assistance Force (ISAF) mission, and the fear of jihadist fighters returning home to China and India from conflict areas abroad, especially from Iraq and Syria highlighted the erosion of the lines between internal and external security of states in BRICS [6]. Regional tensions have been increasing in East Asia since 2008, mainly because of concerns related to maritime territorial disputes, China's strategic assertiveness, nuclear proliferation, military build-up in the region and the fear of a spillover of instability from Afghanistan and Pakistan. So Political discussion at BRICS about national and regional measures aimed at preventing radicalization to terrorism and violent extremism is of utter importance [7]. These discussions will lead to increased focus on security implications of social exclusion in BRICS. It remains to be seen whether BRICS states progressively emphasize a balanced approach that pays equal respect to the various tools of cooperative security, military defence, arms control, crisis management, conflict prevention and conflict resolution.

Development has in the past been defined as economic growth and well-being, and recently it has expanded to 
include capabilities, opportunities and choice [8]. For over 20 years, development has been linked to security through the concept of human security. The relationship can be complex: lagging development can lead to grievance, and conflict can threaten development.

\section{Global Development in Transfer of Major Weapons}

One of the major concerns in BRICS is arms race. Table 1 is the glimps of illustrations of such race where BRICS nations are included in top ten largest exporters and importers of weapons of mass destructions. Since 1950 the USA and Russia (or the Soviet Union before 1992) has consistently been by far the largest suppliers' major weapons. However, China has now firmly established itself as one of the top 5 suppliers: in 2010-14 it was the third largest supplier, narrowly surpassing Germany and France [9]. In fact, global defense policy has always been essentially a zero-sum game, as one country or bloc of countries works to maximize its defense capabilities in ways that (deliberately or indirectly) challenge the military preeminence of its rivals.

\section{Russia}

Russian exports of major weapons increased by 28 per cent between 2004-2008 and 2009-13. Russia delivered weapons to 52 states in 2009-13 but more than half of its exports went to just three countries: India, China and Algeria (see Table 1). Asia and Oceania received 65 per cent of Russian arms exports in 2009-13, followed by Africa (14 per cent) and the Middle East (10 per cent). Russia was the largest exporter of ships in 2009-13, accounting for 27 per cent of all such deliveries. This included the delivery to India of an aircraft carrier and the only nuclear-powered submarine exported in this period. Aircraft accounted for 43 per cent of Russian arms exports in 2009-13, including 219 combat aircraft delivered in this period [10].

\section{China}

Chinese exports of major arms increased by 212 per cent between 2004-2008 and 2009-13, and China's share of global arms exports increased from 2 to 6 per cent. China supplied major arms to 35 states in 2009-13, mainly low- and middle-income countries. Almost three-quarters of Chinese exports went to just three clients: Pakistan, Bangladesh and Myanmar (see Table 1). China's rapidly developing military technology partly explains its expansion as an arms supplier to such countries as Algeria, Morocco and Indonesia, in direct competition with Russia, the USA and European states. In 2013 Turkey a member of the North Atlantic Treaty Organization (NATO) selected China's HQ-9/FD-2000 surface-to-air missile system (SAM) in preference to European, Russian and US alternatives [11].

\section{Brazil}

Brazil's arms imports increased by 65 per cent between 2004-2008 and 2009-13. Even though relations with its neighboring states are generally good, Brazil has started several major and costly arms-procurement programmes. After a long process, partly slowed down by economic constraints, in 2013 Brazil finally selected 36

Table 1. The 10 largest exporters of weapons and their clients 2009-13.

\begin{tabular}{cccccc}
\hline \multirow{2}{*}{ Exporters } & \multicolumn{1}{c}{ Share of International arms exports (\%) } & \multicolumn{2}{c}{ Main clients (share of exporter's total exports) 2009-2013 } \\
\cline { 2 - 6 } & $2009-13$ & $2004-2008$ & 1 st & 2nd & 3rd \\
\hline USA & 29 & 30 & Australia (10\%) & South Korea (10\%) & UAE (9\%) \\
Russia & 27 & 24 & India (38\%) & China (12\%) & Algeria (11\%) \\
Germany & 7 & 10 & USA (10\%) & Greece (8\%) & Israel (8\%) \\
China & 6 & 2 & Pakistan (47\%) & Bangladesh (13\%) & Myanmar (12\%) \\
France & 5 & 9 & China (13\%) & Morocco (11\%) & Singapore (10\%) \\
UK & 4 & 4 & Saudi Arabia (42\%) & USA (18\%) & India (11\%) \\
Spain & 3 & 2 & Norway (21\%) & Australia (12\%) & Venezuela (8\%) \\
Ukraine & 3 & 2 & China (21\%) & Pakistan (8\%) & Russia (7\%) \\
Italy & 3 & 2 & India (10\%) & UAE (9\%) & USA (8\%) \\
Isreal & 2 & 2 & India (33\%) & Turkey (13\%) & Colombia (9\%) \\
\hline
\end{tabular}


JAS-39 Gripen-E combat aircraft from Sweden for an estimated \$4.8 billion. During 2009-13 Brazil also ordered 1 nuclear-powered and 4 Scorpion sub marines from France for $\$ 9.7$ billion and started licensed production of up to 2044 Guarani armored vehicles for $\$ 3.6$ billion from Italy [12].

\section{India}

India's imports of major arms increased by 111 per cent between 2004-2008 and 2009-13, making it the world's largest importer. Its imports 14 per cent of the global total were almost three times larger than those of China or Pakistan, the second and third largest arms importers and regional rivals of India. Russia supplied 75 per cent of Indian arms imports, the USA 7 per cent and Israel 6 per cent. Pakistan's arms imports increased by 119 per cent between 2004-2008 and 2009-13. China provided 54 per cent of Pakistan's imports and the USA 27 per cent. During 2009-13 India and Pakistan both invested heavily in air-strike capabilities. Table 2 gives the lists of countries with world nuclear forces as of 2014 January where we clearly see names of few BRICS nations already and deployed warheads. India received 90 of $222 \mathrm{Su}$-30MKI combat aircraft ordered from Russia. It also received 27 of a total of $45 \mathrm{MiG}-29 \mathrm{~K}$ combat aircraft ordered for use on aircraft carriers. India has 62 Russian MiG-29SMT and 49 French Mirage 2000-5 combat aircraft on order. It has also selected, but not yet ordered, 144 Russian T-50 and 126 French Rafale combat aircraft. Pakistan received 42 JF-17 combat aircraft from China and ordered 100 more. Pakistan also received 18 F-16C combat aircraft from the USA and ordered 13 second-hand F-16Cs from Jordan [13].

Arms control is not achieved in a vacuum. Emphasis should thus be placed on creating a regional cooperation and security system first, and on arms control second; the two sets of discussions go hand in hand. The number of states reporting their arms imports and exports to the United Nations Register of Conventional Arms (UNROCA) decreased in 2014. BRICS should put strong steps towards transparency in arms transfer for its success in all aspects. The protection of civilians must remain high on the BRICS agenda of multilateral peace operations, despite difficulties in implementation.

\section{Prospective of BRICS in International Stabilization and Reconstruction Efforts}

For the suppression of Islamic radicalism and for interests of the secular authoritarian states in Central Asia, BRICS can play major role. BRICS in the region should provide an opportunity from which they could benefit, both geopolitically (in the promotion of their multi-vector foreign policies) and in material terms (in the form of payments for transit and use of infrastructure) [14].

Together with the rising tensions between China and its neighbours in the East and South China Seas, any move to lift the embargo would be highly controversial among parliamentarians, the media and the general public and could also damage relations with important EU trading partners in East Asia [15]. BRICS states should also play an important role in the transportation of supplies to support war affected region. BRICS states have also to provide humanitarian aid and economic and technical assistance to such region.

Table 2. World nuclear forces, 2014.

\begin{tabular}{cccc}
\hline Country & Deployed warheads & Other warheads & Total Inventory \\
USA & $\sim 2100$ & 5200 & $\sim 7300$ \\
Russia & $\sim 1600$ & $\sim 6400$ & $\sim 8000$ \\
UK & 160 & $\sim 65$ & $\sim 225$ \\
France & $\sim 290$ & $\sim 10$ & $\sim 300$ \\
China & & $\sim 250$ & $\sim 250$ \\
India & & $100-110-110$ & $90-100$ \\
Pakistan & & $\sim 80$ & $100-120$ \\
Israel & & & $\sim 80$ \\
North Korea & $\sim \mathbf{4 1 5 0}$ & $\sim \mathbf{1 2 , 2 0 0}$ & $\sim \mathbf{1 6 , 3 5 0}$ \\
Total & &
\end{tabular}

All estimates are approximate and are as of January 2014. 
BRICS states have to express a wide range of security concerns in relation to the withdrawal of ISAF from Afghanistan, including the possibility of greater instability both within Afghanistan itself and in the wider region. However, the ISAF withdrawal, while seen as a source of security challenges, also presents opportunities to BRICS, and experts emphasize the need for international assistance focused on economic recovery. One of the most important facts that BRICS must understand is to avoid policymakers orchestrating "managed chaos" in various parts of the world in order to keep other rising powers from challenging the BRICS's supremacy.

BRICKS perspectives on the prospects for conflict resolution and stabilization lies on mixed factors -political stability and state-building processes, Unity in diversity- ethnic, religious and tribal, Balance of power.

BRICS-led regional framework will be of particular relevance to world security created for collective defence purposes. The framework should in over the years must develop a broader security agenda that includes drug trafficking, human trafficking, organized crime, environmental security and information security. With the goals of countering terrorism and averting external aggression, BRICS should create the collective forces for specific regions and territories that will help in international stabilization.

Furthermore, the incentives and constraints of geopolitical balancing between great powers will shape BRICS policies for international securities and might also create important variations in such policies.

\section{Conclusion}

The transition towards multipolarity in the international system has concerned many observers in recent years. However "BRICS Dream" concept, with envisions that "great renewal of the BRICS nations and the advancement of an international system in which BRICS's successful rise provides an attractive alternate political model to Western ones. Achieving the dream means building a "moderately prosperous society" and a "modern society" that is strong, democratic, cultured, and harmonious. "Peaceful development" and a stable regional environment are essential to create the conditions for this vision. This is based partly on the assumption that multipolarity will create cooperation based on their own geostrategic, economic or political interests. The BRICS dream leads the strong allies army dream, and the strong allies army dream supports the international stabilization. BRICS modernization must alter the security balance in the Asia and Asia Pacific, should challenge decades of U.S. military preeminence in the region. The BRICS expanding involvement in real world missions allows it to field-test equipment and obtain hands-on experience in areas such as addressing unconventional threats in harsh and potentially hostile environments, satisfying expeditionary logistics requirements, and integrating into multilateral operations.

\section{Conflict of Interests}

The authors declare that there is no conflict of interests regarding the publications of this research paper. Selected for final Round and Presented in BRICS Round table-Ministry of Education and Science of the RUSSIAN Federation (CRIMEA)].

\section{References}

[1] Kayani, S.A. (2015) Afghanistan and Central Asian States (Turkmenistan, Uzbekistan and Tajikistan): Post 2014. FWU Journal of Social Sciences, 1, 44.

[2] McMillan, J., Sokolsky, R. and Winner, A.C. (2003) Toward a New Regional Security Architecture. Washington Quarterly, 26, 161-175. http://dx.doi.org/10.1162/016366003765609642

[3] Jones, P. (2007) Is a Common Threat Perception a Necessary Precondition for the Creation of a Regional Security and Co-Operation System? Conflict in Focus, No. 21, October 2007, 3-5.

[4] Dewitt, D. (1994) Common, Comprehensive, and Cooperative Security. The Pacific Review, 7, 1-15. http://dx.doi.org/10.1080/09512749408719067

[5] European Security. www.sipri.org/yearbook/2015/06

[6] Olimova, C.K. and Olimov, M.A. (2014) Problem of 2014: A View from Central Asia, Challenges to Security in Central Asia. Conference Proceedings, Institute of World Economy and International Relations, Russian Academy of Sciences (IMEMO RAS) and Foundation for Prospective Studies and Initiatives (PSIF), Moscow, Nov., 77-82. http://www.imemo.ru/files/File/ru/publ/2013/13002.pdf

[7] Balci, B. (2013) The Myth of Rising Islamic Extremism in Post-(2014) Central Asia. World Politics Review, 30 December 2013. 
[8] Kuchins, A.C., Sanderson, T.M. and Gordon, D.A. (2009) The Northern Distribution Network and the Modern Silk Road: Planning for Afghanistan's Future: A Report of the CSIS Transnational Threats Project and the Russia and Eurasia Program. CSIS.

[9] Wezeman, P.D. and Wezeman, S.T. (2015) Trends in International Arms Transfers, 2014. SIPRI.

[10] All Guns Firing: Russian Arms Trade on the Rebound. 22 March 2014 RAKESH KRISHNAN SIMHA. http://in.rbth.com/blogs/2014/03/22/all_guns_firing_russian_arms_trade_on_the_rebound_33927.html

[11] Xia, M. (n.d.) “China Threat” or a "Peaceful Rise of China”. New York Times China Rises Companion. http://www.nytimes.com/ref/college/coll-china-politics-007.html

[12] Nuclear NavalPropulsion|LeonamGuimaraesAcademia.edu. http://www.academia.edu/6558674/Nuclear Naval Propulsion

[13] Billionsto Upgrade and Up-Arm Pakistan's F-16s. http://www.defenseindustrydaily.com/51b-proposed-in-sales-upgrades-weapons-for-pakistans-f16s-02396/

[14] Kassenova, N. (2014) Relations between Afghanistan and Central Asian States after 2014: Incentives, Constraints and Prospects.

[15] Wray, L. (2015) China's Maritime and Territorial Claims to the South China Sea: A Focus on the Key Centres of Gravity Driving the South China Sea Disputes. Journal of the Australian Institute of Professional Intelligence Officers, 23, 3.

\section{Warmly welcome your paper submission to OALib Journal!}

- Publication on a daily basis

- 9 subject areas of science, technology and medicine

- Fair and rigorous peer-review system

- Fast publication process

- Article promotion in various social networking sites (LinkedIn, Facebook, Twitter, etc.)

- Widely-targeted and multidisciplinary audience to read your research

Submit Your Paper Online: Click Here to Submit

Contact Us: service@oalib.com 